\title{
Evaluation of performance of different barley genotypes irrigated with saline water in South Tunisian Saharan conditions
}

\author{
Zied Hammami ${ }^{1 *}$, Hanen Sbei ${ }^{1}$, Karim Kadri' ${ }^{2}$, Zied Jmel ${ }^{1}$, Ali Sahli ${ }^{1}$, Makram Belhaj Fraj ${ }^{3}$, \\ Hafed Naser ${ }^{4}$, Jaime A. Teixeira da Silva ${ }^{5}$, Youssef Trifa ${ }^{1}$ \\ ${ }^{1}$ Laboratory of Cereal Genetics, National Institute of Agriculture of Tunisia 43, Avenue Charles Nicole, 1082 Tunis, Tunisia \\ ${ }^{2}$ Centre Régional des Recherches en Agriculture Oasienne, 2260 Dégache, Tunisia \\ ${ }^{3}$ International Center for Biosaline Agriculture,P. O. Box 14660, Dubai, United Arab Emirates \\ ${ }^{4}$ National Institute of Research of Rural Engineering, Waters and forests of Tunis, Tunisia, BP 10 Ariana 2080, Tunisia \\ ${ }^{5}$ P. O. Box 7, Miki-cho post office, Ikenobe 3011-2, Kagawa-ken, 761-0799, Japan \\ ${ }^{\star}$ Corresponding author, E-mail: hammamizied@live.fr
}

\begin{abstract}
Barley (Hordeum vulgare L.) is an important crop in Tunisia, especially in the south, which is characterized by an arid Saharan climate. Water resources, when available, are saline. In this study, 26 barley genotypes were evaluated in Saharan conditions. Plants were irrigated with saline water. Germination percentage, height, leaf area, tiller number, percentage of senescing leaves, leaf chlorophyll content, shoot dry weight and grain yield varied significantly between genotypes. This implies that important intraspecific genetic variation in this germplasm exists in response to salinity and aridity. The estimated grain yield of the introduced cultivar '113/1B' and a local landrace 'Ardhaoui 'reached $1.1 \mathrm{t} \mathrm{ha}^{-1}$, despite these saline and arid conditions, and exceeded the overall national average yield of about $0.75 \mathrm{t} \mathrm{ha}{ }^{-1}$. Selection of these genotypes can be profitable when grown in marginal areas using brackish water. The soil electric conductivity did not increase at the experimental location following saline irrigation: $2.30 \mathrm{dS} \mathrm{m}^{-1}$ at sowing and $2.37 \mathrm{dS} \mathrm{m}^{-1}$ at harvest, indicating that there is no risk of salt accumulation in sandy soil.
\end{abstract}

Key words: barley, Saharian environment, salinity, yield.

Abbreviations: CC, total chlorophyll conten; DAS, days after sowing; EC, electrical conductivity; GP, germination percentage; GY, grain yield; LA, leaf area; OM, organic matter; PCA, principal component analysis; PDL, percentage of dead leaves; PH, plant height; SDW, shoot dry weight; TN, tiller number.

\section{Introduction}

Agriculture is a major sector of the Tunisian economy. However, Tunisia is represented by a Saharan arid and semiarid regions. Crops in these regions cannot be irrigated by rainfall, which is rare. In addition, salt concentration in the water of reservoirs and wells is 3 to $8.5 \mathrm{dS} \mathrm{m}^{-1}$ and 6 to 10

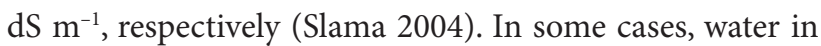
wells can reach $14 \mathrm{dS} \mathrm{m}^{-1}$, particularly in arid and Saharan areas. In this region, salinity in soil or irrigation water is the major limiting factor to crop growth (Ashraf et al. 2008; Kausar et al. 2013) and is a major abiotic stress affecting agricultural production.

One way to exploit these areas and saline water sources is to improve the salt tolerance of cultivated species. This would be useful for local communities, including cereals, especially barley (Hordeum vulgare L.). However, despite its importance as food and feed in these areas (El Felah, Medimagh 2005), barley culture is relatively marginalized by farmers and the average grain yield in Southern
Tunisia never exceeds $0.5 \mathrm{t} \mathrm{ha}^{-1}$ (GDPA 2009). This low productivity is due to environmental limitations such as desertification and salinity as well as socio-economic constraints. On the other hand, the importance of barley derives from its ability to grow and produce in marginal environments, which are often characterized by drought, high temperature and salinity (Slama 2005; Al-Dakheel et al. 2012). The salinity tolerance of barley is $8.0 \mathrm{dS} \mathrm{m} \mathrm{m}^{-1}$ (Maas, Hoffman 1997; Tabatabaei, Anagholi 2013). Barley is also considered a model species for cereals due to its widely available genetic information (Hayes et al. 2002). Consequently, the improvement of abiotic stress tolerance in barley depends largely on exploiting the available genetic variation. In addition, using cultivars tolerant to salinity allows the conservation of freshwater and its conservative use, mainly in arid areas (Keating et al. 2010).

The objectives of the present investigation were to study the possibility of extending and ameliorating the barley crop in marginal, Saharan areas. To achieve this, we examined the effects of irrigation with saline water $\left(\mathrm{EC}=13 \mathrm{dS} \mathrm{m}^{-1}\right)$ 
on the dynamics of salinization and evolution of soil $\mathrm{pH}$ in an experimental plot (Chamsa-Tozeur) during the 20092010 cropping season, and to determine variability between 26 barley cultivars in response to severe abiotic stress.

\section{Materials and methods}

\section{Plant material}

In total, 26 varieties of barley were used, consisting of three local landraces ('Ardhaoui', 'Arbi Abidh' and barley 'Mednine'), four improved Tunisian barley cultivars ('Rihane,'Tej,' 'Konouz,'Manel') and 19 introduced cultivars (Pakistain cultivars: 'PK 30109', 'PK 30046, 'PK 30163', 'PK 30118'; Batini landraces from Oman: '113/1B', '100/1B', '186 $\mathrm{AD}$ ', $\mathrm{AD} / 87$ ', '111/4A,' '16/2A'; 'Furat 1' from Syria, 'Giza 125' from Egypt; IPA7 from Iraq; 'Alanda-01' from ICARDA; 'Rihane-03' from ICARDA; 'Barjouj' from Libya; 'ICARDA 20 ' from ICARDA; and 'Saudi' from Saudi Arabia) obtained from the National Research Institute for Rural Engineering, Water and Forestry, Ariana, Tunisia in collaboration with the International Center for Biosaline Agriculture, Dubai, United Arab Emirates (Table 1).

Table 1. Categories and origin of the barley genotypes used in the study

\begin{tabular}{llll} 
Code & Genotype & $\begin{array}{l}\text { Breeding } \\
\text { status }\end{array}$ & Origin \\
\hline 1 & 'Rihane' & Cultivar & Tunisia \\
\hline 2 & 'Tej' & Cultivar & Tunisia \\
\hline 3 & 'Konouz' & Cultivar & Tunisia \\
\hline 4 & 'Manel' & Cultivar & Tunisia \\
\hline 5 & 'Arbi Abidh' & Landrace & ICARDA/Syriea \\
\hline 6 & 'Barley Mednine' & Landrace & ICARDA/Tunisia \\
\hline 7 & 'Ardhaoui' & Landraces & Tunisie \\
\hline 8 & 'PK 30046' & Landrace & Pakistan \\
\hline 9 & 'PK 30109' & Landrace & Pakistan \\
\hline 10 & 'PK 30163' & Landrace & Pakistan \\
\hline 11 & 'PK 30118' & Landrace & Pakistan \\
\hline 12 & '100/1B' & Landrace & Oman \\
\hline 13 & '111/4A' & Landrace & Oman \\
\hline 14 & '113/1B' & Landrace & Oman \\
\hline 15 & 'AD/87' & Landrace & Oman \\
\hline 16 & '186 AD' & Landrace & Oman \\
\hline 17 & '16/2A' & Landrace & Oman \\
\hline 18 & 'Rihane-03' & Cultivar & ICARDA \\
\hline 19 & 'IPA7' & Cultivar & Iraq \\
\hline 20 & 'Furat 1' & Cultivar & Syria \\
\hline 21 & 'Giza 125' & Cultivar & Egypt \\
\hline 22 & 'Alanda-01' & Cultivar & ICARDA \\
\hline 23 & 'Rihane 3' & Landraces & ICARDA \\
\hline 24 & 'ICARDA 20' & Cultivar & ICARDA \\
\hline 26 & 'Baudi' & Landrace & Saudi Arabia \\
& & Cultivar & Libya \\
\hline
\end{tabular}

\section{Experimental site}

The Tunisian oasis covers approximately 40800 ha (Sghaier 2010), about $13 \%$ of the irrigated area of the country (Hajji 1997). We selected a site near an oasis due to the ability to draw on brackish water. The experimental site near the Chamsa oasis (Fig. 1) is characterized by a Saharan bioclimate, high temperature and little, irregular rainfall $\left(<90 \mathrm{~mm}\right.$ year $\left.{ }^{-1}\right)$. Evapotranspiration is high (1800 to 2000 $\left.\mathrm{mm} \mathrm{year}^{-1}\right)$ and insulation is very high $\left(3061 \mathrm{~h} \mathrm{year}^{-1}\right)$. In Tunisia, continental winds are dry and cold during winter, and dry and hot during summer, with an average of 120 days year ${ }^{-1}$ of sandstorms and 40 days year ${ }^{-1}$ of sirocco (National Institute of Meteorology, Tunis, Tunisia, 2010).

Weather conditions during the 2009/2010 growing season are detailed in Table 2. The total accumulated precipitation during this season was $35 \mathrm{~mm}$. Mean and maximum temperatures recorded during November 2009 to May 2010 were 22.3 and $45.2^{\circ} \mathrm{C}$, respectively.

Field experiments were conducted during the 2009/2010 cropping season near the Chamsa oasis $\left(33^{\circ} 58^{\prime} 00.67^{\prime \prime} \mathrm{N}\right.$; $\left.8^{\circ} 02^{\prime} 05.78^{\prime \prime} \mathrm{E}\right)$. The experiment was designed as a randomized complete block with three replications. Each cultivar was sown in a $2 \mathrm{~m}^{2}$ area $(2 \times 1 \mathrm{~m})$, in 10 lines spaced $20 \mathrm{~cm}$ apart. The cultivation density was determined based on 200 seeds $\mathrm{m}^{-2}$, the weight of 1000 seeds and the germinability of each cultivar. Plots were irrigated using a flood irrigation system with natural groundwater that had an EC equal to $13 \mathrm{dS} \mathrm{m}^{-1}$ (i.e., saline, brackish water). The EC of water was measured with a conductiviometer (Consort C830, Turnhout, Belgium).

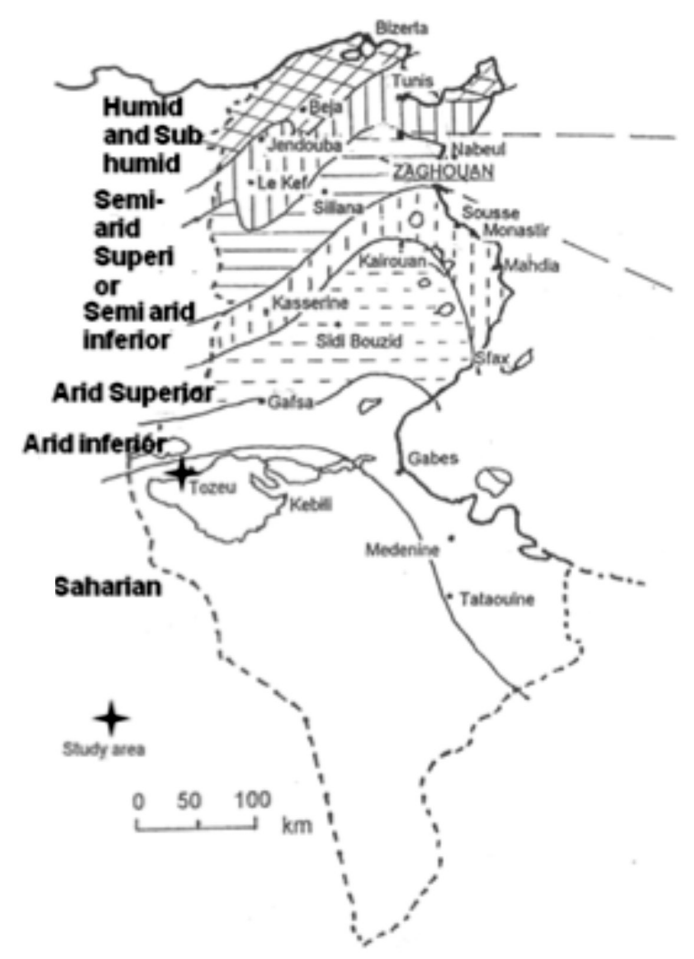

Fig. 1. Bioclimatic zones of Tunisia, including the study area. 
Table 2. Agro-meteorological parameters of the experimental site

$\begin{array}{lccccccccc} & \text { October } & \text { November } & \text { December } & \text { January } & \text { February } & \text { March } & \text { April } & \text { May } & \text { June } \\ \text { Rainfall }(\mathrm{mm}) & 0 & 2 & 5 & 5.1 & 0 & 9 & 0 & 0 & 0 \\ \begin{array}{l}\text { Average } \\ \text { temperature }\left({ }^{\circ} \mathrm{C}\right)\end{array} & 22 & 21.7 & 18.0 & 17.8 & 18.4 & 21.7 & 28.2 & 30.5 & 22.5 \\ \begin{array}{l}\text { Maximal } \\ \text { temperature }\left({ }^{\circ} \mathrm{C}\right)\end{array} & 33.3 & 31.4 & 26.6 & 25 & 30.3 & 39.8 & 40.2 & 45.2 & 37 \\ \end{array}$

\section{Soil analysis}

A soil auger was used to extract soil samples to a depth of $1 \mathrm{~m}$ from the soil surface of the experimental plot. At each grid point (one per block), disturbed soil samples were taken at vertical depth increments ( 0 to $0.2,0.2$ to $0.4,0.4$ to $0.6,0.6$ to 0.8 , and 0.8 to $1 \mathrm{~m}$ ). Physico-chemical analyses were performed on soil dried for 45 days in the open air and sieved to $2 \mathrm{~mm}$. Total organic nitrogen concentration was determined by the Kjeldahl method (Kjeldahl 1883; Skoog et al. 1997). Granulometric fractions were determined by sedimentation, pipetting after de-carbonation, and destruction of organic matter (OM) (Pansu, Gautheyrou 2006). Phosphorus and labile potassium concentrations were determined by the Olsen method (Baize 2000) on dried soil and were extracted with a solution of sodium bicarbonate. The concentration of these elements in filtrate was determined by a spectrophotometer (UV1800, Shimadzu Corp., Kyoto, Japan) at $\lambda=840 \mathrm{~nm}$. The levels of nitrogen, phosphorus and potassium were evaluated (low or appropriate) by comparison with the standards proposed by Calvet and Villemin (1986). Soil $\mathrm{pH}$ and EC were measured in an extract of $1 / 5$, according to the method of Pawels et al. (1992), using a pH meter (Consort C830, Parklaan 36, B2300 Turnhout, Belgium) and conductivimeter, respectively.

\section{Agromorphological analysis}

Agronomic and physiological measurements were made at two growth stages: tillering stage at 100 days after sowing (DAS) and maturation stage at 145 DAS. A morphological evaluation was performed on eight agronomic parameters: germination percentage (GP) (\%), plant height (PH) $(\mathrm{cm})$, leaf area (LA) $\left(\mathrm{cm}^{2}\right)$, tiller number (TN) (per plant), percentage of dead leaves (PDL) (\%), total chlorophyll content (CC), shoot dry weight (SDW) $\left(\mathrm{g} \mathrm{m}^{-2}\right)$ and grain yield (GY) $\left(\mathrm{g} \mathrm{m}^{-2}\right)$.

At the tillering stage, three plants were taken randomly from each experimental unit, thus nine plants for each germplasm were used in the analysis. $\mathrm{pH}$ was determined using a $\mathrm{pH}$ meter (Consort C830, Parklaan 36, B2300 Turnhout, Belgium). SDW was calculated by drying each sample in an oven for $48 \mathrm{~h}$ at $80^{\circ} \mathrm{C}$. The third leaf of the main axis of nine plants was scanned and LA was measured by image software Mesurim Pro-02-08 (Madre, Academy of Amiens, France). Chlorophyll content was determined on the third leaf (three readings) of nine plants of each plot, thus 27 plants for each germplasm, using a portable chlorophyll meter (Minolta SPAD 502 Meter, Osaka, Japan). The percentage of dead leaves was determined as the number of dead leaves from base to tip of plants divided by the total number of leaves. At grain maturity (145 DAS), plants from $1 \mathrm{~m}^{2}$ from each plot were harvested to estimate GY.

\section{Statistical analysis}

Data were statistically analyzed using analysis of variance (ANOVA) $(p<0.05)$, using SPSS Version 16.0 for Windows (SPSS Inc., Chicago, IL, USA). Descriptive statistical analysis and principal component analysis (PCA) were performed with Excel (version 2003, Microsoft, Seattle, WA) add-in XLSTAT-PRO version 5.2 (AddinSoft, New York, NY).

\section{Results and discussion}

\section{Soil}

This study assessed whether barley could be extended as a crop to more marginal desert areas (Chamsa oasis region) in south Tunisia by irrigating soils with saline water (EC = $13 \mathrm{dS} \mathrm{m}^{-1}$ ). Granulometric analysis showed that the soil is sandy loam type. All the soil layers had a low OM content

Table 3. Characteristics of soil at the Chamsa-Tozeur experimental station at different depths. $\mathrm{K}$, potassium ion; $\mathrm{P}_{\text {ass, }}$ assimilable phosphorus

\begin{tabular}{lcccccccc} 
Depth (cm) & Clay (\%) & Silt (\%) & Sand (\%) & $\begin{array}{c}\text { Organic } \\
\text { matter (\%) }\end{array}$ & Nitrogen (\%) & $\begin{array}{c}\text { Labile K}^{+} \\
\left(\mathbf{m g ~ k g}^{-1}\right)\end{array}$ & $\begin{array}{c}\mathbf{P}_{\text {ass }} \\
\left(\mathbf{m g ~ k g}^{-1}\right)\end{array}$ \\
\hline $0-20$ & 0 & 13.50 & 85.49 & 0.89 & 0.02 & 120.00 & 1.74 \\
\hline $20-40$ & 0 & 24.07 & 75.93 & 0.25 & 0.02 & 113.33 & 2.00 \\
$40-60$ & 0 & 30.30 & 69.49 & 0.59 & 0.03 & 106.66 & 1.62 \\
$60-80$ & 0 & 27.78 & 72.22 & 1.40 & 0.02 & 153.33 & 1.63 \\
$80-100$ & 0 & 22.00 & 77.17 & 0.12 & 0.02 & 120.00 & 2.25 \\
\hline
\end{tabular}



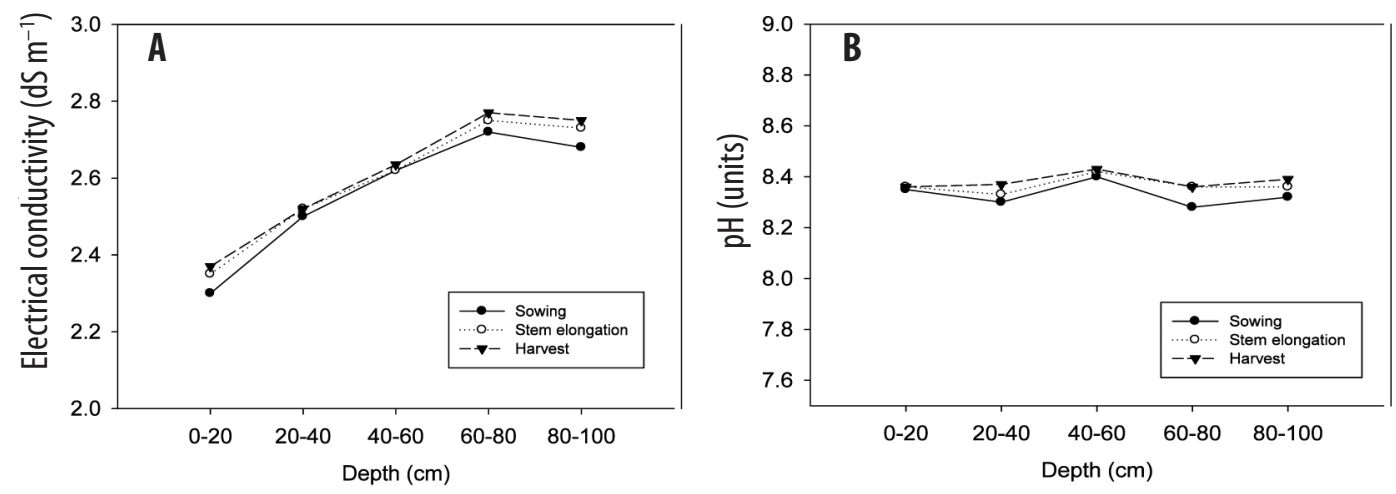

Fig. 2. Salinization dynamics (A) and evolution of soil pH (B) at the experimental plot (Chamsa-Tozeur) in 2009-2010.

$(<1$; Table 3). Generally, in arid regions, OM is low or nonexistent (Mtimet 2001) while barley requires at least $0.5 \%$ OM (Brink et al. 2006). The soil had a very low content of nitrogen $(0.02 \%)$, phosphorus ( $122 \mathrm{mg} \mathrm{kg}^{-1}$ ) and potassium $\left(1.8 \mathrm{mg} \mathrm{kg}^{-1}\right)$. This result was explained, on one hand, by the absence of annual fertilization, and on the other, by the high mobility of these elements in soil, especially nitrogen (Bertschinger et al. 2003), combined with high filteration of sandy loam soil. These elements, which are essential for crop production, are generally provided by fertilizers. Therefore, low levels of these elements in the soils of the Tunisian south can be corrected by suitable fertilization. In addition, nutrients needs of barley are generally very low compared to that of other cereals (Brink et al. 2006; Robert et al. 2007).

EC increased with soil depth but salinity remained relatively unchanged throughout the cropping season (Fig. 2A). Among cereals, rice (Oryza sativa) is the most sensitive and barley is the most tolerant (Munns, Tester 2008). Therefore, barley is considered as an ideal model plant for genetic and physiological studies on salt tolerance. Barley is widely cultivated in saline areas as one of the most salt-tolerant field crops (Munns et al. 2006).

Soil $\mathrm{pH}$ of the experimental plot was basic and remained relatively unchanged throughout the experimental period, with a slight increase in deeper horizons (Fig. 2B). Arid soils are generally alkaline with a pH between 8 and 8.5 (Daoud, Halitim 1994). Biological activity of soil and availability of most nutrients are dependent on $\mathrm{pH}$ (Bertschinger et al. 2003). Soil in the southern region of Tunisia was basic. Indeed, several studies confirm that in arid regions, soils are generally alkaline with a $\mathrm{pH}$ value between 8 and 8.5 (Daoud, Halitim 1994). For wheat culture, the optimal pH value is between 5.5 and 7.5 (Brink et al. 2006). However, $\mathrm{pH}$ close to 8 is not considered as a limiting factor for the development of durum wheat (Brink et al. 2006). High pH values ( 8 to 8.5$)$ are frequently associated with difficulty in plant assimilation of elements like phosphorus, zinc, manganese, copper and iron (Heller et al. 1998). Also, micronutrient deficiencies are common in soil having acid or alkaline $\mathrm{pH}$ (FAO 2003), resulting in the formation of insoluble hydroxides (Heller et al. 1998).

\section{Yield variation}

The average grain yield was $0.38 \mathrm{t} \mathrm{ha}^{-1}$ (Table 4). This performance was similar to the average national Tunisian production of barley over several years: $0.28,0.19,0.41$ and $0.22 \mathrm{t} \mathrm{ha}^{-1}$ in $1994,1995,2000$ and 2002, respectively (GDAP 2009). These levels were also similar to the southern average yield most of the time. In this study, yield reached $1.16 \mathrm{t} \mathrm{ha}^{-1}$ under salt stress, better than the national average yield in 2009 and 2008 which was about 0.75 and $0.8 \mathrm{tha}^{-1}$, respectively (GDAP 2009). All the phenotypic parameters (GP, PH, TN, PDS, CC and LA) varied widely between genotypes, in some cases exceeding $100 \%$ variation, since their potential and response to stress differed. Jaradat et al. (2004) estimated genetic variation for salinity tolerance in the Batini landrace to be $73 \%$. Al-Dakheel et al. (2012)

Table 4. Descriptive statistical analysis for parameters GP, H, TN, PDL, CC, LA, BY and GY for different barley cultivars. GP, germination percentage; GY, grain yield; LA, leaf area; PH, plant height; PDL, percentage of dead leaves; SDW, shoot dry weight; CC, leaf chlorophyll content; TN, tiller number

\begin{tabular}{|c|c|c|c|c|c|c|c|c|}
\hline & GP (\%) & $\mathrm{PH}(\mathrm{cm})$ & TN & PDL & $\mathrm{CC}$ & LA $\left(\mathrm{cm}^{2}\right)$ & $\begin{array}{l}\text { SDW } \\
\left(\mathrm{g} \mathrm{m}^{-2}\right)\end{array}$ & GY $\left(\mathrm{t} \mathrm{ha}^{-1}\right)$ \\
\hline Min. & 46.50 & 18.40 & 1 & 30.04 & 17.11 & 6.73 & 39.21 & 0.064 \\
\hline Max. & 89.00 & 32.72 & 3 & 68.61 & 42.24 & 16.66 & 111.78 & 1.163 \\
\hline $\begin{array}{l}\text { General } \\
\text { means }\end{array}$ & 65.33 & 26.40 & 1.8 & 48.83 & 33.72 & 10.60 & 60.00 & 0.378 \\
\hline
\end{tabular}


Table 5. Variance analysis of measured traits estimates for 26 barley genotypes. ${ }^{*}$, ${ }^{*}$, significant at $\mathrm{P}=0.05$ level and $\mathrm{P}=0.01$, respectively; df, degrees of freedom; GP, germination percentage; GY, grain yield; LA, leaf area; PH, plant height; PDL, percentage of dead leaves; SDW, shoot dry weight; CC, leaf chlorophyll content; TN, tiller number

$\begin{array}{lccccccccc}\begin{array}{l}\text { Source of } \\ \text { variation }\end{array} & \text { Df } & \text { GP }(\%) & \text { PH }(\mathbf{c m}) & \text { LA }\left(\mathbf{c m}^{2}\right) & \begin{array}{c}\text { SDW } \\ \left(\mathbf{g ~ m}^{-2}\right)\end{array} & \text { TN } & \text { PDL }(\%) & \text { CC } & \left.\text { GY }(\mathbf{g ~ m})^{-2}\right) \\ \text { Cultivars } & 25 & 305.68^{*} & 124.83^{* *} & 53.74^{* *} & 0.14^{* *} & 1.25^{*} & 531.76^{*} & 462.19^{* *} & 1468.85^{*} \\ \text { R2 } & & 0.48 & 0.38 & 0.21 & 0.25 & 0.16 & 0.18 & 0.35 & 0.62 \\ \text { CV } & & 19.28 & 19.72 & 48.68 & 47.57 & 49.04 & 36.17 & 32.34 & 71.13\end{array}$

also reported wide genotypic differences by barley cultivars consisting of Batini landrace material, which included 234 entries selected from 2308 entries and international breeding material from ICARDA, differing in salt tolerance after irrigation with saline water in response to salinity stress. However, the observed level of tolerance was $8 \mathrm{dS}$ $\mathrm{m}^{-1}$.

A response to abiotic stress generally occurs in most crops by affecting morphological parameters (Jaradat et al. 2004). Results obtained from ANOVA indicated significant differences between cultivars for all traits (Table 5). However, barley is considered to be the most salt-tolerant cereal (Jiang et al. 2006, Megan et al. 2013). Our results revealed large variability within the 26 genotypes for salt stress. Thus, for similar salinity stresses, the levels of tolerance in barley vary depending on the genotype (Munns et al. 2006). The variation in plant height between genotypes was the most commonly observed effect of salt stress, as confirmed by several studies (Kadri et al. 2009, Samah et al. 2013). In response to water deficit caused by salinity, plants reacted by reducing biomass. In particular, the reduction of leaf area was observed in local genotype 'Ardaoui' and the two Batini landraces '113/1B' and '100/1B'. Parida et al. (2005) showed that salinity can reduce dry weight. The significant effect of genotype on leaf chlorophyll content showed that abiotic stress, especially salinity, affects nutrient uptake and metabolic activities in plants to different degrees (Othman et al. 2006). Barley genotypes showed also variation in tolerance to salinity at germination stage. Many authors have observed that germination percentage varies between genotypes when irrigated with salinity solution (Naseri et al. 2012). Emam (2011) indicated that seed germination and seedling establishment are the periods when barley is most sensitive to salinity, as was observed for introduced cultivars 'Rihane-03' and 'IPA7' and improved Tunisian genotypes.

Principal component analysis (PCA) based on all variables was used to discriminate between genotypes (Fig. 3). PCA1 axis, which explained $33 \%$ of total variability, is a linear combination of CC, LA and GY. PCA2 axis represents $25 \%$ of total variability and is influenced by $\mathrm{PH}, \mathrm{PDL}$ and SDW. PCA could distinguish four groups, one of which was adapted to abiotic stress, shown by good GY.

The first group was composed of genotypes with the best morphological performance. The second group was a subgroup of the first group and was composed of genotypes in which the best GY was observed, indicating successful completion of the life cycle, and included some introduced varieties such as the two Batini landraces '113/1B', '100/1B' and 'Giza 125'. This result was similar to the result of evaluations for salt tolerance by Al-Dakheel and Belhaj Fraj (2012) and Jaradat et al. (2004) for Batini, and by Noaman (1995) and Jiang et al. (2006) for 'Giza 125'. In addition, the Tunisian landraces Arbi Abidh and Ardhaoui fall into this second group. El Faleh et al. (1991) showed that under abiotic stress, the local landraces barley 'CRG134' and 'CRG334' performed better than improved barley such as 'Ceres,' Martin', and 'Faiz Rihane'.

The third group was composed of genotypes with poor GY, including improved Tunisian genotypes ('Konous', 'Rihane' and 'Manel') and two introduced accessions, 'IPA7' and 'Alanda-01'. Najar et al. (2010) indicated that improved Tunisian genotypes ('Manel', 'Rihane' and 'Martin') were developed for favourable growing conditions in northern Tunisia. The fourth group was composed of genotypes with the highest percentage of dead leaves, which was associated with very poor biological performance and GY. The percentage of dead leaves has been used in several studies to screen tolerance to abiotic stress, especially salt stress, such as in bread wheat (Michael et al. 2011). Avoiding leaf senescence allows the plant to maintain transpiration and increase photosynthates, which accumulate during the

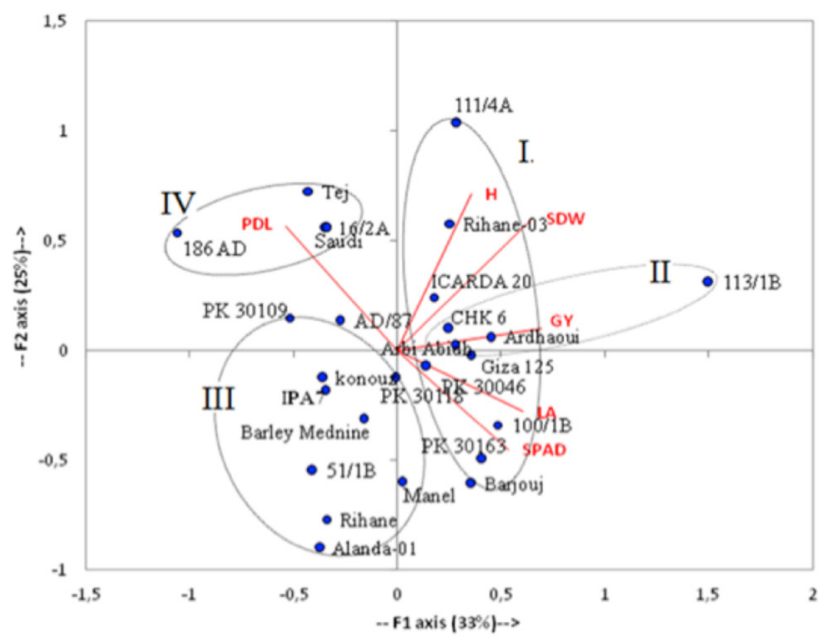

Fig. 3. Principal component analysis of 26 barley accessions 
crop's life cycle (Borrell et al. 2001). This was also observed in our study since, according to PCA, this parameter was inversely correlated with the leaf chlorophyll content (Fig. 3). According to Munns et al. (2006), acceleration of senescence was due to either high leaf $\mathrm{Na}^{+}$concentrations or to low tolerance of the accumulated $\mathrm{Na}^{+}$.

\section{Conclusions}

Introduced cultivars ('113/1B', '100/1B' and 'Giza 125') and local genotypes ('Arbi Abidh' and 'Arthaoui') showed the highest tolerance at a high level of salinity under a Saharan climate. These genotypes can be profitable in marginal areas using brackish water and, through appropriate selection and breeding programs, can be utilized for further improving salt tolerance of Tunisian barley genotypes. The study of the dynamics of soil salinization showed no risk of salt accumulation in sandy soils of the Chamsa region, suggesting the sustainability of barley production when irrigated with saline water.

\section{References}

Al-Dakheel A.J., Belhaj Fraj M. 2012. Assessing biomass and grain yields stability of a restricted collection of Batini barley landraces from Oman under salinity stress. Scholarly J. Agric. Sci. 2: 13-17.

Al-Dakheel A.J., Belhaj Fraj M., Shabbir G.M., Al Gailani A.Q.M. 2012. Evaluation of Batini barley landraces from Oman and breeding lines under various irrigation salinity levels. Agric. Sci. Res. J. 2: 42-50.

Alem C., Labhilili M., Brahimi K., Jlibene M., Nasrallah N., FilaliMaltouf A. 2002. Adaptations hydrique et photosynthétique du blé dur et du blé tendre au stress salin. C. R. Biol. 325: 1097-1109.

Ashraf M., Athar H.R., Harris P.J.C., Kwon T.R. 2008. Some prospective strategies for improving crop salt tolerance. $A d v$. Agron. 97: 45-110.

Baize D. 2000. Guide des analyses en pédologie. 2ème INRA Editions, Paris. 266 p.

Bertschinger L., Gysi C., Häseli A., Neuweiler R., Pfammatter W., Ryser J.P., Schmid A., Weibel F. 2003. Données de base pour la fumure en arboriculture fruitière. FAW Fascicule 15, ACWWädenswil. 48 p.

Borrell A., Hammer G., Van Oosterom E. 2001. Stay-green: a consequence of the balance between supply and demand for nitrogen during grain filling? Ann. Appl. Biol. 138: 91-95.

Brink H., van der Walt C., van Rensburg G. 2006. Fundamentals of Research. Methodology for Health-care Professionals. Juta, Cape Town. 226 p.

Calvet G., Villemin P. 1986. Interprétation des analyses de terre, IPAS, SADEF-SCPA, Aspach le Bas, France. p 25.

Daoud Y., Halitim A. 1994. Irrigation et salinisation au Sahara Algérien. Sécheresse 5: 151-160.

El Felah M., Chalbi N., El Gazzah M. 1991. Analyse de l'adaptation à l'aridité de quelques ressources génétiques locales d'orge (Hordeum vulgare L.) comparativement à des variétés améliorées. In: Lamélioration des plantes pour l'adaptation aux milieux arides. AUPELF/UREF, John Libbey Eurotext, Paris, pp. 197-209.

El Felah M., Medimagh S. (2005). Food barley in Tunisia. In: Grando S., Gormez H. (eds.) Food Barley: Importance, Uses and Local Knowledge. Proceedings of the International Workshop on Food Barley Improvement. ICARDA, Aleppo Syria, pp. 29-35.

Emam Y. 2011. Cereal Production. $4^{\text {th }}$ ed. Shiraz University Press, Shiraz, Iran.

FAO 2003. Gestion intégrée des ressources naturelles eaux et sols de l'Afrique du Nord - Synthèse et propositions. Bureau sousrégional pour l'Afrique du Nord. Tunis, $91 \mathrm{p}$.

GDAP 2009. General Direction of Agriculture Production, Ministry of Agriculture and Hydraulics Resources, Tunisia 2009.

Hajji A. 1997. La modernisation des oasis tunisiennes: acquis et défis. In: Jouve A.M. (ed.) La modernisation des agricultures méditerranéennes (à la mémoire de Pierre Coulomb). Montpellier: CIHEAM. Options Méditerranéennes : Séminaires Méditerranéens, pp. 257-264.

Hayes P.M., Castro A., Marquez-Cedillo L., Corey A., Henson C., Jones B., Kling J. 2002. Genetic diversity for quantitatively inherited agronomic and malting quality traits. In: von Bothmer R., Knuepfer H., van Hintum T., Sato K. (eds) Diversity in Barley - Hordeum vulgare. Elsevier Science Publishers, Amsterdam, pp. 201-226.

Heller K.G., Korsunovskaya O., Ragge D.R., Vedenina V., Willemse F., Zhantiev R.D., Frantsevich L. 1998. Check-list of European Orthoptera. Articulata Beiheft 7: 1-61.

Jaradat A.A., Shahid M., Al-Maskri A.Y. 2004. Genetic diversity in the Batini barley landrace from Oman: Spike and seed quantitative and qualitative traits. Crop Sci. 44: 304-315.

Jiang Q.Z., Roche D., Monaco T.A., Durham S. 2006. Gas exchange, chlorophyll fluorescence parameters and carbon isotope discrimination of 14 barley genetic lines in response to salinity. Field Crop Res. 96: 269-278.

Kadri K., Maalam S., Cheikh M.H., Benabdallah A., Rahmoune C., Ben Naceur M. 2009. Effet du stress salin sur la germination, la croissance et la production en grains de quelques accessions tunisiennes d'orge (Hordeum vulgare L.). Sci. Tech. C 29: 72-79.

Kausar F., Shahbaz M., Ashraf M. 2013. Protective role of foliar applied nitric oxide in Triticum aestivum under saline stress. Turk. J. Bot. 37: 1155-1165.

Keating B.A., Carberry P.S., Bindraban P.S., Asseng S., Meinke H., Dixon J. 2010. Eco-efficient agriculture: concepts, challenges, and opportunities. Crop Sci. 50: 109-119.

Kjeldahl J. 1883. Neue Methode zur Bestimmung des Stickstoffs in organischen Körpern. Z. Anal. Chem. 22: 366-382.

Maas E.V., Hoffman G.J. 1997. Crop salt tolerance - current assessment. J. Irrig. Drain. 103: 115-134.

Mahler R.L., Guy S.O. 2007. Northern Idaho Fertilizer Guide: Spring Barley. University of Idaho, Fertilizer Guide CIS 920. $4 \mathrm{p}$.

Michael O., Adu D., Sparkes L., Parmar A., Yawson D.O. 2011.'Stay green' in wheat: comparative study of modern bread wheat and ancient wheat cultivars. J. Agric. Biol. Sci. 6: 16-24.

Mtimet A. 2001. Soils of Tunisia. In: Zdruli P., Steduto P., Lacirignola C., Montanarella L. (eds.) Soil Resources of Southern and Eastern Mediterranean Countries. CIHEAM, Bari. Options Méditerranéennes, Etudes et Recherches 34: 243-262

Munns R., James R.A., Läuchli A. 2006. Approaches to increasing the salt tolerance of wheat and other cereals. J. Exp. Bot. 57: 
1025-1043.

Najar A., Benghanem H., Aloui-Rezgui S., Rezgui S., Nasraoui B. 2010. Evaluation of three fungal disease attacks in relation to agronomic performances of some barley lines initially selected for their resistance to Barley Yellow Dwarf Virus. Tun. J. Plant Protect. 5: 9-17.

Naseer S., Nisar A., Ashraf M. 2001. Effect of salt stress on germination and seedling growth of barley (Hordeum vulgare L.). Pak. J. Biol. Sci. 4: 359-360.

Naseri R., Emami T., Mirzaei A., Soleymanifard A. 2012. Effect of salinity (sodium chloride) on germination and seedling growth of barley (Hordeum vulgare L.) cultivars. Int. J. Agri. Crop. Sci. 4: 911-917.

Noaman M.M., El-Sayed A.A., Asaad F.A., El-Sherbini A.M., ElBawab A.Q., El-Moselhi M.A., Rizk R.A. 1995. Registration of 'Giza 125' barley. Crop Sci. 35: 1701-1709.

Othman Y., Al-Karaki G., Al-Tawaha A.R., Al-Horani A. 2006. Variation in germination and ion uptake in barley genotypes under salinity conditions. World J. Agric. Sci. 2: 11-15.

Pansu M., Gautheyrou J. 2006. Handbook of Soil Analysis, Mineralogical, Organic and Inorganic Methods. SpringerVerlag, Berlin,p. 993.

Parida A.K., Das A.B. 2005. Salt tolerance and salinity effects on plants. Rev. Ecotoxicol. Environ. Safety 60: 324-349.
Pauwels J.M., van Rust E., Verloo M., Mvoudo Z.E. 1992. Manuel de laboratoire de pédologie: Méthodes d'analyses des sols et des plantes. Publications Agricole, France. 28 p.

Samah A.M, Maher N.M., Khatab I., Antar N.B., Abdel Khalek A.F., Al-Dinary M.E. 2013. Genetic diversity analysis of some barley genotypes for salt tolerance using SSR markers. J. Agric. Sci. 5: 12-28.

Sghaier M.2010. Etude de la gouvernance des ressources naturelles dans les oasis cas des oasis en Tunisie. Union Internationale pour la Conservation de la Nature. Décembre 2010.

Shelden M.C., Roessner U. 2013. Advances in functional genomics for investigating salinity stress tolerance mechanisms in cereals. Front. Plant Sci. 4:1-8.

Skoog D.A., West D.M., Holler F.J. 1997. Chimie analytique. Traduction et révision scientifique de la 7e édition américaine, De Boeck Université, Paris. 1176 p.

Slama A. 2005. Les céréales en Tunisie: production, effet de la sécheresse et mécanismes de résistance. Sécheresse 16: 225229.

Slama F. 2004. La salinité et la production végétale. Centre de Publication Universitaire Tunis, 163 p.

Tabatabaei S.A., Anagholi A. 2013. Determination of the salinity tolerance indices in barley (Hordeum vulgare) varieties. Int. J. Agric. Crop. Sci. 16: 1752-1754. 